\title{
Plasma Electrolytic Oxidation (PEO) coatings on a zirconium alloy for improved wear and corrosion resistance
}

\author{
Y. Chen, X. Nie \& D. O. Northwood \\ Department of Mechanical, Automotive and Materials Engineering, \\ University of Windsor, Canada
}

\begin{abstract}
$\mathrm{Zr}$ oxide coatings were deposited using plasma electrolytic oxidation (PEO) on $\mathrm{Zr}-2.5 \mathrm{wt} \% \mathrm{Nb}(\mathrm{Zr}-2.5 \mathrm{Nb})$ alloy, which is currently used for pressure tubes in the CANDU nuclear reactor. The effects of two PEO processing factors, electrolyte concentration and current density, on the microstructure and properties of the coatings were systematically investigated. The coating morphology and chemical composition were determined using scanning electron microscopy (SEM) and energy dispersive X-ray analysis (EDX). Potentiodynamic polarization corrosion testing was used to examine the corrosion resistance of the coatings in a dilute aqueous, $\mathrm{LiOH}$ solution. Pin-on-disc wear tests were performed under dry and lubricated sliding conditions. SEM was also used to characterize the wear traces on the coated and uncoated surfaces. A 30-day autoclave experiment was carried out to study the corrosion performance of the $\mathrm{Zr}-2.5 \mathrm{Nb}$ substrate, PEO coatings and a commercial autoclaved black oxide coating. Based on the results of this research, recommendations are made as to processing parameters for the production of oxide coatings with improved wear and corrosion resistance.
\end{abstract}

Keywords: Zr-2.5Nb, PEO, commercial black oxide coating, corrosion and wear resistance, autoclave.

\section{Introduction}

$\mathrm{Zr}-2.5 \mathrm{wt} \% \mathrm{Nb}$ (hereafter, referred to as $\mathrm{Zr}-2.5 \mathrm{Nb}$ ) has been used in CANDUPHW type nuclear reactors for the manufacture of pressure tubes (PT) because of its low neutron absorption cross-section, high corrosion resistance, high strength and creep resistance [1-4]. The inside surfaces of the PTs are in contact with 
lithiated heavy water $\left(\mathrm{D}_{2} \mathrm{O}\right)$ coolant at 250 to $300{ }^{\circ} \mathrm{C}$ and as a result of a corrosion reaction, deuterium (hydrogen) is formed [2]. Between 5 and $10 \%$ of this deuterium may be absorbed by $\mathrm{Zr}-2.5 \mathrm{Nb}$ during normal operation which could degrade the mechanical properties. The cold-worked $\mathrm{Zr}-2.5 \mathrm{Nb}$ alloy PTs are autoclaved in steam at $400^{\circ} \mathrm{C}$ for $24 \mathrm{hrs}$ to produce a black adherent oxide film of 1 to $2 \mu \mathrm{m}$ in thickness which has proven to be an excellent hydrogen permeation barrier [2]. CANDU-PHW reactors utilize on-power refuelling and there is wear between the fuel bundle wear-pads and the inside surface of the PT which can lead to localized material degradation. Recent trends to higher fuel burn-up, extended recycle, high $\mathrm{PH}$ operation and higher operating temperatures, have led to the need of improve the corrosion and wear resistance of $\mathrm{Zr}-2.5 \mathrm{Nb}$.

Plasma electrolytic oxidation (PEO) is a technique by which a oxide or other ceramic coating can be grown in-situ on $\mathrm{Al}, \mathrm{Ti}, \mathrm{Mg}$ and many other light metals [5-11]. In PEO technology, sparks or arc plasma microdischarges in an aqueous solution are used to ionize gaseous media from the solution with the result that complex compounds are synthesized on the metal surface by the plasmachemical interactions. It was used, first of all, for the surface hardening and enhancement of the corrosion resistance of $\mathrm{Al}$ [5-9] and, more recently, $\mathrm{Mg}$ and Ti alloys [10-12]. Thus far, it has had limited application to $\mathrm{Zr}$ alloys $[12,13]$.

\section{Experimental details}

Square coupons with dimensions of $15 \times 13 \times 4 \mathrm{~mm}^{3}$ were cut from commercial $\mathrm{Zr}$ $2.5 \mathrm{Nb}$ PT with black oxide coating on both surfaces (fig 1). The coupons were carefully polished flat to obtain uniform a surface roughness of $R_{a}=0.1 \pm 0.02 \mu \mathrm{m}$. Other coupons with the black oxide coating retained were cut to a similar geometric size for comparison.

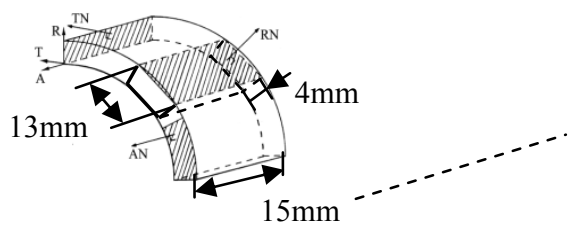

Figure 1: Schematic diagram showing the sample coupon cutting method.

A PEO technique was used to deposit ceramic coatings on $\mathrm{Zr}-2.5 \mathrm{Nb}$ substrates using pulsed DC power with a frequency of $2000 \mathrm{~Hz}$ supply in a silicate: $\mathrm{KOH}$ electrolyte. Two different $\mathrm{Na}_{2} \mathrm{SiO}_{3}: \mathrm{KOH}$ solutions with concentration ratios of $8 \mathrm{~g} / \mathrm{L}: 0.8 \mathrm{~g} / \mathrm{L}$ and $8 \mathrm{~g} / \mathrm{L}: 8 \mathrm{~g} / \mathrm{L}$ were used. Different treatment times and current densities were used (table 1). Near constant thickness $(5 \mu \mathrm{m})$ coatings were produced on all coupons.

Potentiodynamic polarization tests were carried out using a Bio-Logic SP-150 potentiostat/galvanostat for uncoated, PEO-coated and inside surface of black oxide samples at room temperature $\left(20^{\circ} \mathrm{C}\right)$ in a $4.8 \mathrm{wt} . \%(0.2 \mathrm{~mol} / \mathrm{L}$ or $1400 \mathrm{ppm}$ $\left.\mathrm{Li}^{+}\right) \mathrm{LiOH}$ solution, which is very corrosive to $\mathrm{Zr}$ alloys [14, 15]. The exposure area of the samples was $1 \mathrm{~cm} 2$. Scans were conducted from $-0.5 \mathrm{~V}$ to $2 \mathrm{~V}$. 
Table 1: $\quad$ Treatment parameters for PEO coatings.

\begin{tabular}{|c|c|c|c|}
\hline $\begin{array}{c}\text { Composition } \\
\left(\mathrm{Na}_{2} \mathrm{SiO}_{3}: \mathrm{KOH}\right)\end{array}$ & $\begin{array}{c}\text { Sample } \\
\text { No. }\end{array}$ & $\begin{array}{c}\text { Current } \\
\text { density }\left(\mathrm{A} / \mathrm{cm}^{2}\right)\end{array}$ & $\begin{array}{c}\text { Treatment } \\
\text { time (min) }\end{array}$ \\
\hline $\begin{array}{c}\text { Group } \mathrm{A} \\
\text { Electrolyte I }(\mathrm{Ph}=11-12) \\
(8 \mathrm{~g} / \mathrm{L}: 0.8 \mathrm{~g} / \mathrm{L})\end{array}$ & $\mathrm{S} 1$ & 0.05 & 4 \\
\cline { 2 - 4 } & $\mathrm{S} 2$ & 0.1 & 2 \\
\cline { 2 - 4 } Group B & $\mathrm{S} 3$ & 0.25 & 0.8 \\
\hline \multirow{2}{*}{$\begin{array}{c}\text { Electrolyte II }(\mathrm{Ph}=13-14) \\
(8 \mathrm{~g} / \mathrm{L}: 8 \mathrm{~g} / \mathrm{L})\end{array}$} & $\mathrm{S} 4$ & 0.05 & 4 \\
\cline { 2 - 4 } & $\mathrm{S} 5$ & 0.1 & 0.8 \\
\cline { 2 - 4 } & $\mathrm{S} 6$ & 0.25 & \\
\hline
\end{tabular}

An accelerated corrosion test involving 30-day autoclave exposure to high temperature $\left(300^{\circ} \mathrm{C}\right)$, high pressure $(10 \mathrm{MPa})$ and $0.05 \mathrm{~mol} / \mathrm{L} \mathrm{LiOH}$ solution was carried out to simulate the service conditions of PTs [16]. The test was interrupted at 2, 5, 10, 15, 30 days to refresh the $\mathrm{LiOH}$ solution and make measurements. In each period, the samples were removed from the autoclave, dried and weighed. Some samples of selected exposure times were then examined by potentiodynamic polarization tests. The others were then put back into the autoclave for another cycle.

The tribological properties were tested by a pin-on-disc tribometer at room temperature. Two modes were used: rotating mode (sliding speed: $0.1 \mathrm{~m} / \mathrm{s}$ ) for flat samples (both substrate and the PEO samples) and reciprocating mode (sliding speed: $0.08 \mathrm{~m} / \mathrm{s}$ ) for the curved samples (black oxide coating). All the PEO coatings were first tested at $2 \mathrm{~N}$ normal load and $1000 \mathrm{~m}$ sliding distance under dry conditions. The uncoated substrate was also tested at the same conditions and load but only to a 50m sliding distance. Surface roughness was measured across the wear trace to study its width and depth. One of the PEO coatings (S1), which showed good wear resistance, was chosen for reciprocating wear tests to compare it with the black oxide coating. In the reciprocating wear test, both dry and lubricated conditions at 2 and $5 \mathrm{~N}$ load respectively were used. The sliding distance was $1000 \mathrm{~m}$ but the test was stopped at coating failure.

JEOL Scanning Electron Microscope at an operating voltage of $18 \mathrm{keV}$ with EDX were employed to study coating thickness, surface morphology and chemical composition.

\section{Results and discussion}

\subsection{Characterization of PEO coatings}

As seen in table 1, six sets of PEO coatings were made. SEM examination was made of both the coating surface and cross-section through the sample thickness.

SEM micrographs of selected PEO coatings (S1, S2 and S5) and the commercial black oxide coating are shown in fig 2 for the surface morphology and fig 3 for the cross-sections. Sample S1, which was fabricated at a current density of $0.05 \mathrm{~A} / \mathrm{cm}^{2}$, exhibited a relatively dense, continuous oxide film, see figs 2(a) and 3(a). Samples S2 and S5, which were fabricated at a higher current 
density $\left(0.1 \mathrm{~A} / \mathrm{cm}^{2}\right)$ exhibited significant porosity (figs 2(b) and (c) and figs 3(b) and (c)). At higher current densities, the discharges are more intense and its pores act as discharge channels. The black oxide coating is about $1 \mu \mathrm{m}$ thick and also contains porosity: The porosity is finer than in PEO samples S2 and S5.
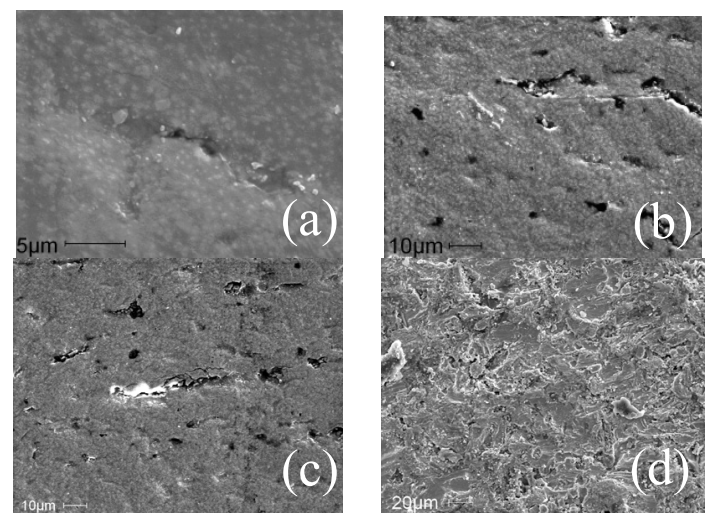

Figure 2: $\quad$ SEM micrographs on the morphology of (a) and (b) S1 and S2 in electrolyte I; (c) S5 in electrolyte II; (d) Black oxide coating.
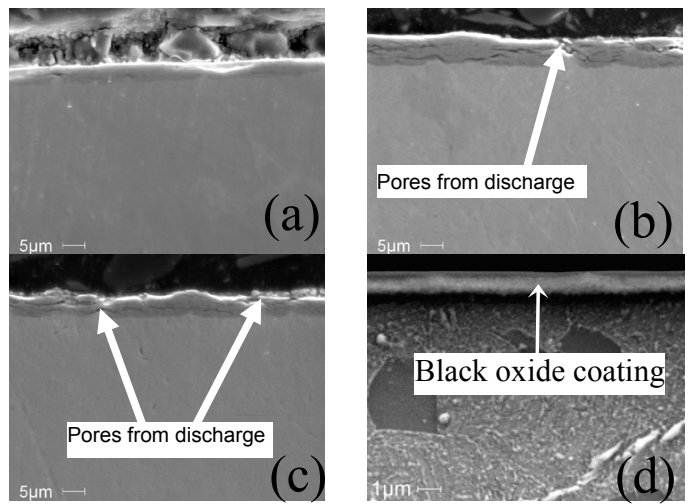

Figure 3: Cross-sectional SEM micrographs at different magnifications of the PEO coatings. (a) and (b) S1 and S2 in electrolyte I; (c) S5 in electrolyte II; (d) Black oxide coating.

\subsection{Corrosion tests}

\subsubsection{Potentiodynamic polarization tests}

Fig 4 shows the polarization curves for the $\mathrm{Zr}-2.5 \mathrm{Nb}$ substrate both without and with the black oxide coating and PEO coated samples. Values for the corrosion potential $\left(\mathrm{E}_{\text {corr }}\right)$ and corrosion current $\left(\mathrm{i}_{\text {corr }}\right)$ and polarization resistance $\left(\mathrm{R}_{\mathrm{p}}\right)$ are given in table 2 . 
The corrosion potentials $\left(\mathrm{E}_{\text {corr }}\right)$, corrosion current density $\left(\mathrm{i}_{\text {corr }}\right)$, and anodic/cathodic Tafel slopes $\left(b_{a}\right.$ and $\left.b_{c}\right)$ were obtained from these results. Then, based on an approximate linear polarization at the corrosion potential, the polarization resistance $\left(R_{p}\right)$ values were determined using the relationship $[6,11]$ :

$$
R_{p}=\frac{b_{a} \times b_{c}}{2.303 \times i_{c o r r}\left(b_{a}+b_{c}\right)}
$$

It can be seen that all PEO coatings and the black oxide coating had much lower $\mathrm{i}_{\text {corr }}$ compared to $\mathrm{Zr}-2.5 \mathrm{Nb}$ substrate (as much as one to two orders of magnitude) and the $\mathrm{E}_{\text {corr }}(-0.21 \mathrm{~V}$ to $-0.28 \mathrm{~V})$ are higher than the substrate $(-0.35 \mathrm{~V})$. At the point $\mathrm{E}=0.78 \mathrm{~V}$, the $\mathrm{i}_{\text {corr }}$ of the $\mathrm{Zr}-2.5 \mathrm{Nb}$ substrate increased significantly. This is because the thin protective oxide film on the $\mathrm{Zr}-2.5 \mathrm{Nb}$ substrate surface broke down and large craters were formed (see insert in fig. 4).

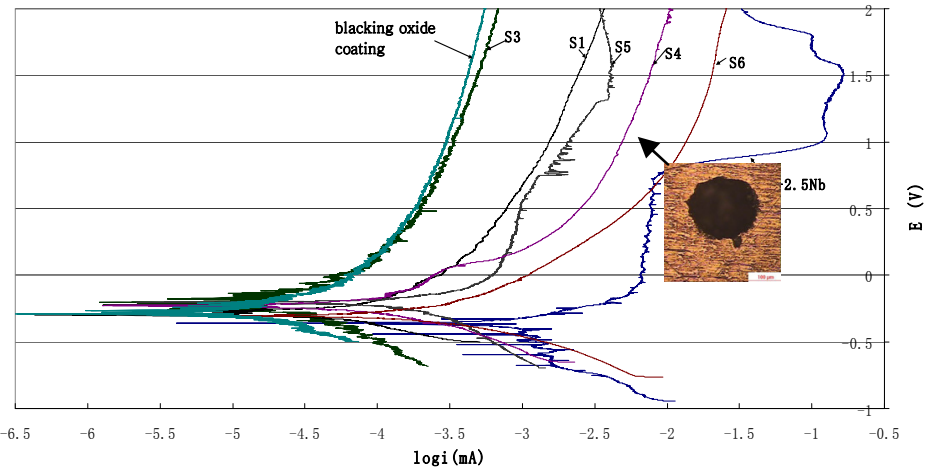

Figure 4: Potentiodynamic polarization curves of the uncoated $\mathrm{Zr}-2.5 \mathrm{Nb}$, coated samples and black oxide coating.

Table 2: Results of potentiodynamic polarisation tests in a $0.2 \mathrm{~mol} / \mathrm{L} \mathrm{LiOH}$ solution.

\begin{tabular}{|c|c|c|c|}
\hline Samples & $\mathrm{i}_{\text {corr }}\left(\mathrm{mA} / \mathrm{cm}^{2}\right)$ & $\mathrm{E}_{\text {corr }}(\mathrm{V})$ & $\mathrm{R}_{\mathrm{p}}\left(\Omega \mathrm{cm}^{2}\right)$ \\
\hline Zr-2.5Nb substrate & $1.02 \mathrm{E}-03$ & -0.35 & $1.22 \mathrm{E}+04$ \\
\hline Black oxide coating & $1.12 \mathrm{E}-05$ & -0.28 & $3.57 \mathrm{E}+06$ \\
\hline $\mathrm{S} 1\left(0.05 \mathrm{~A} / \mathrm{cm}^{2}, 8: 0.8\right)$ & $6.31 \mathrm{E}-05$ & -0.25 & $1.22 \mathrm{E}+06$ \\
\hline $\mathrm{S} 2\left(0.1 \mathrm{~A} / \mathrm{cm}^{2}, 8: 0.8\right)$ & $5.71 \mathrm{E}-05$ & -0.27 & $1.39 \mathrm{E}+06$ \\
\hline $\mathrm{S} 3\left(0.25 \mathrm{~A} / \mathrm{cm}^{2}, 8: 0.8\right)$ & $1.58 \mathrm{E}-05$ & -0.22 & $1.58 \mathrm{E}+06$ \\
\hline $\mathrm{S} 4\left(0.05 \mathrm{~A} / \mathrm{cm}^{2}, 8: 8\right)$ & $7.08 \mathrm{E}-05$ & -0.25 & $5.72 \mathrm{E}+05$ \\
\hline $\mathrm{S} 5\left(0.1 \mathrm{~A} / \mathrm{cm}^{2}, 8: 8\right)$ & $1.58 \mathrm{E}-04$ & -0.21 & $2.68 \mathrm{E}+05$ \\
\hline $\mathrm{S} 6\left(0.25 \mathrm{~A} / \mathrm{cm}^{2}, 8: 8\right)$ & $2.09 \mathrm{E}-04$ & -0.28 & $2.06 \mathrm{E}+05$ \\
\hline
\end{tabular}

From table 2, it can be seen that PEO coatings made in electrolyte I have a better corrosion resistance than those made in electrolyte II. It is in agreement with previous studies of the production of PEO coatings on $\mathrm{Al}$, where alkaline electrolytes are widely used, but too high in $\mathrm{PH}$ value may have negative effect on the growth of passive films [5]. The thin commercial black oxide coating shows excellent corrosion resistance in these potentiodynamic polarization tests. 


\subsubsection{Autoclave experiment}

Fig. 5 shows how the weight gain of samples changed with the exposure time in the autoclave. The weight gain of PEO coatings increased quickly in the first two days and then slowed down. This may explained by the dissolution of the oxygen from the solution into the outer layer of the PEO coating which is not very dense and forms $\mathrm{ZrO}_{2}$ together with other intermediate lower oxides. However, there was a very thin, inner dense layer close to the oxide/metal interface which worked as an excellent barrier to the oxygen ingress, so the corrosion rate after 2 days slowed down. However, after exposure beyond a certain point (transition point), all coated samples had an abrupt increase in corrosion rate. Comparing two groups, it can be found that samples in Group A had a longer pre-transition period (in the range of 10 to 30 days) than those in Group B (in the range of 5 to 10 days). The weight gains of Group A were almost the same (0.76-0.87\%). Due to the spalling of oxide layers in Group B samples, it was difficult to measure the weight gain after 10 days in autoclave. Thus, the weight gain data after the 10day point in Group B shows a decrease compared to shorter exposure times.

(a)

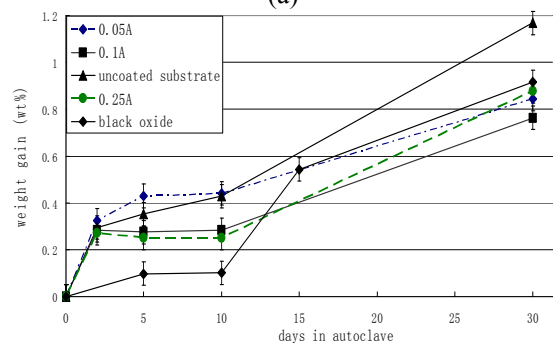

(b)

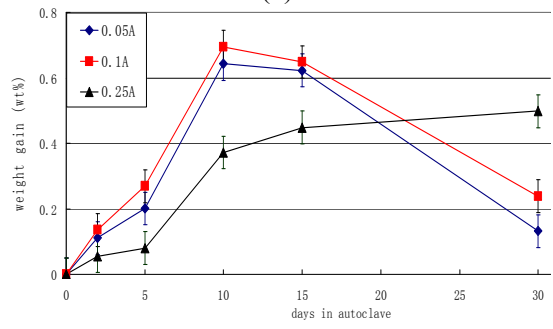

Figure 5: Weight gain vs. treatment time: (a) Group A, substrate and black oxide coating; (b) Group B.

The uncoated substrate and black oxide coating were also tested up to 30 days. As with the PEO coated samples, the weight of substrate firstly increased rapidly because of the formation of a protective film. This dark, thin film was a protective but was not as dense as the PEO coatings. Unlike the PEO coatings in Group B, where coatings were spalled off entirely, the coating formed on the uncoated substrate consists of several thin layers formed parallel to the oxide/metal interface [17]. When a certain thickness of oxide is attained, the outer layer of oxide will crack into small pieces, separate from the sample surface and sink to the bottom of the autoclave. In this case, the weight gain data recorded in Fig 5(a) for the substrate is much lower than its real value. However, the final weight gain (about $1.18 \%$ ) is still higher than the PEO coatings. The black oxide coating shows an excellent corrosion prevention property in the first 10 days (better than all the PEO coatings). But, for long exposure times, it exhibited a similar weight gain to the PEO coatings $(0.92 \%)$.

Fig. 6 is SEM micrographs showing surface morphologies of the two groups of PEO coatings and black oxide coating. Figs 6 (a) and (b) show the surface morphology of sample S1 after 5 and 30 days in the autoclave. The coating was still adherent and protective since its $R_{p}$ value was still higher than the substrate 
(table 3). Unlike sample S1, sample S4 which was fabricated using a different electrolyte but the same current condition, behaved differently-almost all the coating flaked away from the metal (fig 6(c)). Instead of the PEO oxide, a newly formed oxide (fig 6 (c), (d)) quickly grew beneath the initial layer. This new oxide was white, soft and provided very little corrosion protection. After 30 day exposure, the PEO coating had spalled-off entirely, and a 'new' oxide, which was over $20 \mu \mathrm{m}$ thick, covered the whole surface (fig 6 (e), (f)). A thick, white oxide grew on the top of the black oxide coating (fig $6(\mathrm{~g})$, (h) after 30 days in autoclave, but this oxide was different from the PEO coatings in its morphology. A flocculent structure with a large amount of pores was formed.

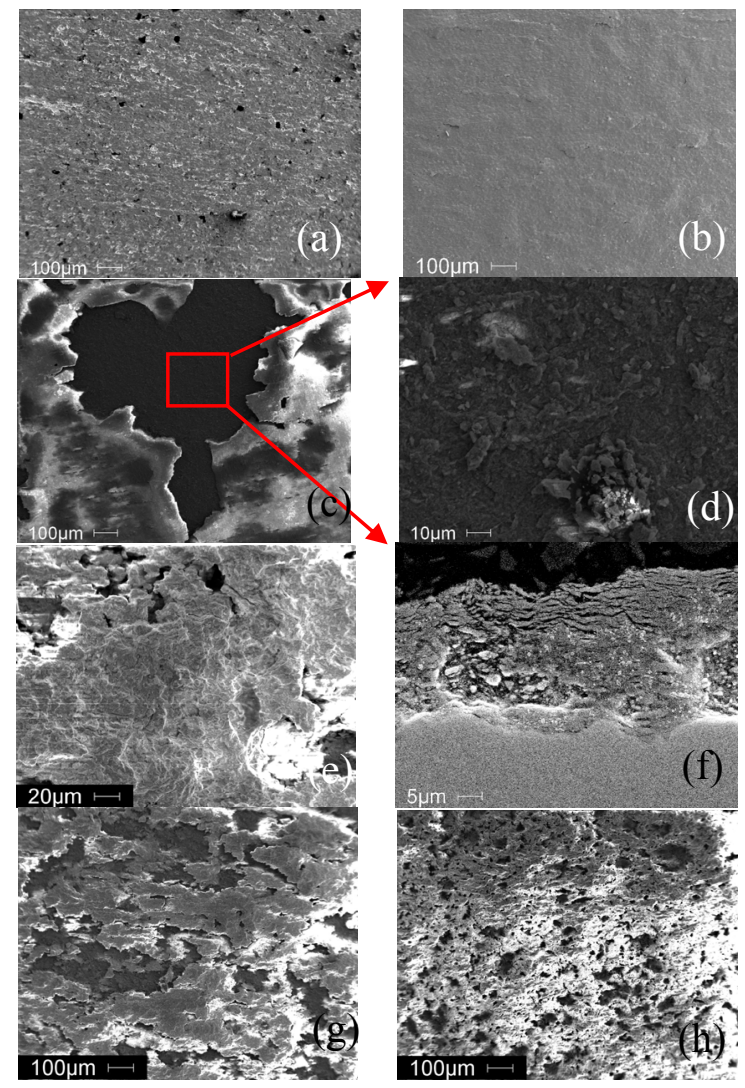

Figure 6: Morphology of the samples during the autoclave corrosion test under different magnifications: (a), (b) S1 after 5 and 30 days; (c)-(f) S4 in 15 and 30 days; (g), (h) inside surface of black oxide coating in 5 and 30 days respectively in autoclave.

Table 3 shows the potentiodynamic polarization results for specimens retested after the autoclave testing. From table 3, the thin oxide formed in first 5 days in $300^{\circ} \mathrm{C}$ aqueous environment acts as an excellent oxidation barrier but its corrosion resistance decreases with the exposure time after a critical time. It can 
be seen that with an increase of the exposure time, the value of $i_{\text {corr }}$ increase greatly together with a slight increase of $\mathrm{E}_{\text {corr }}$. In this case, the $\mathrm{R}_{\mathrm{p}}$ for both coated and uncoated samples decreased by more than an order of magnitude. The $R_{p}$ value of coatings of Group B decreased more rapidly than that in Group A. However, it is interesting to note that all PEO coatings had a better corrosion resistance than the 'newly-made' PEO ones after 5 days in autoclave. It was suggested that the small pores in 'newly made' PEO coatings were closed by heating in the autoclave for a short period of time.

Table 3: Results of the potentiodynamic polarization tests on samples removed from autoclave corrosion tests at fixed time intervals.

\begin{tabular}{|c|c|c|c|c|}
\hline $\begin{array}{c}\text { Days in } \\
\text { autoclave }\end{array}$ & Samples & $\mathrm{i}_{\text {corr }}\left(\mu \mathrm{A} / \mathrm{cm}^{2}\right)$ & $\mathrm{E}_{\text {corr }}(\mathrm{mV})$ & $\mathrm{R}_{\mathrm{p}}\left(\Omega \mathrm{cm}^{2}\right)$ \\
\hline 0 day & $\mathrm{Zr}-2.5 \mathrm{Nb}$ & 1.02 & -330.2 & $1.22 \mathrm{E}+04$ \\
\hline \multirow{5}{*}{5 days } & $\mathrm{Zr}-2.5 \mathrm{Nb}$ & 0.02 & -195.54 & $1.08 \mathrm{E}+06$ \\
\cline { 2 - 5 } & $\mathrm{S} 1$ & 0.015 & -205.34 & $1.23 \mathrm{E}+06$ \\
\cline { 2 - 5 } & $\mathrm{S} 2$ & 0.028 & -190.9 & $1.12 \mathrm{E}+06$ \\
\cline { 2 - 5 } & $\mathrm{S} 3$ & 0.019 & -264.18 & $1.91 \mathrm{E}+06$ \\
\cline { 2 - 5 } & $\mathrm{S} 4$ & 0.029 & -202.54 & $1.77 \mathrm{E}+06$ \\
\cline { 2 - 5 } & $\mathrm{S} 5$ & 0.029 & -329.5 & $1.05 \mathrm{E}+06$ \\
\cline { 2 - 5 } & $\mathrm{S} 6$ & 0.025 & -184.23 & $1.28 \mathrm{E}+06$ \\
\hline \multirow{4}{*}{ 10 days } & $\mathrm{S} 1$ & 0.122 & -251.9 & $3.38 \mathrm{E}+05$ \\
\cline { 2 - 5 } & $\mathrm{S} 2$ & 0.18 & -229.1 & $2.61 \mathrm{E}+05$ \\
\cline { 2 - 5 } & $\mathrm{S} 3$ & 0.123 & -245.4 & $4.4 \mathrm{E}+05$ \\
\hline \multirow{5}{*}{ days } & $\mathrm{S} 4$ & 0.206 & -186.74 & $2.38 \mathrm{E}+05$ \\
\cline { 2 - 5 } & $\mathrm{S} 5$ & 0.3 & -260.1 & $1.53 \mathrm{E}+05$ \\
\cline { 2 - 5 } & $\mathrm{S} 6$ & 0.128 & -281.7 & $9.04 \mathrm{E}+04$ \\
\hline & $\mathrm{Zr}-2.5 \mathrm{Nb}$ & 0.374 & -265.3 & $9.21 \mathrm{E}+04$ \\
\cline { 2 - 5 } & $\mathrm{S} 1$ & 0.231 & -251.9 & $1.22 \mathrm{E}+05$ \\
\cline { 2 - 5 } & $\mathrm{S} 2$ & 0.313 & -127.2 & $9.31 \mathrm{E}+04$ \\
\cline { 2 - 5 } & $\mathrm{S} 3$ & 0.282 & -171.6 & $1.0 \mathrm{E}+05$ \\
\cline { 2 - 5 } & $\mathrm{S} 4$ & 0.39 & -221.8 & $5.3 \mathrm{E}+04$ \\
\cline { 2 - 5 } & $\mathrm{S} 5$ & 0.273 & -193.6 & $4.98 \mathrm{E}+04$ \\
\cline { 2 - 5 } & $\mathrm{S} 6$ & 0.313 & +30.451 & $6.0 \mathrm{E}+04$ \\
\hline
\end{tabular}

\subsection{Pin-on-disc tests}

The wear test results are summarized in table 4 for the rotating mode and table 5 for the reciprocating mode. Tables 4 and 5 show almost all the PEO coatings had not failed after a $1000 \mathrm{~m}$ sliding distance in both rotating and reciprocating mode of testing. The black oxide coating, both under dry and lubricated conditions, showed inferior wear resistance. After wear testing, roughness data was collected across the wear trace to compare the mass loss (fig 7). A 50m wear distance for the $\mathrm{Zr}-2.5 \mathrm{Nb}$ substrate produced a $10 \mu \mathrm{m}$-deep wear trace, whereas a $1000 \mathrm{~m}$ wear distance under same load produced only a $1.5 \mu \mathrm{m}$-deep trace for PEO-coated 
sample (S4). As mentioned in part 3.1, the PEO coating ( $5 \mu \mathrm{m}$ thick) was not penetrated.

Table 4: Wear/failure distances of coated and uncoated samples under rotating mode.

\begin{tabular}{|c|c|c|c|c|c|c|c|}
\hline $\begin{array}{c}\text { Rotating } \\
\text { mode }\end{array}$ & $\mathrm{Zr}-2.5 \mathrm{Nb}$ & $\mathrm{S} 1$ & $\mathrm{~S} 2$ & $\mathrm{~S} 3$ & $\mathrm{~S} 4$ & $\mathrm{~S} 5$ & $\mathrm{~S} 6$ \\
\hline $\begin{array}{c}\mathrm{dry} / 2 \mathrm{~N} / \\
\mathrm{v}=0.1 \mathrm{~m} / \mathrm{s}\end{array}$ & $50 \mathrm{~m}$ & $\begin{array}{c}1000 \\
\mathrm{~m}\end{array}$ & $\begin{array}{c}970 \mathrm{~m} \\
\text { (failed) }\end{array}$ & $\begin{array}{c}1000 \\
\mathrm{~m}\end{array}$ & $\begin{array}{c}1000 \\
\mathrm{~m}\end{array}$ & $\begin{array}{c}1000 \\
\mathrm{~m}\end{array}$ & $\begin{array}{c}910 \mathrm{~m} \\
\text { (failed) }\end{array}$ \\
\hline
\end{tabular}

Table 5: Wear/failure distance of coated and uncoated samples under reciprocating mode.

\begin{tabular}{|c|c|c|c|}
\hline Reciprocating mode & $\mathrm{Zr}-2.5 \mathrm{Nb}$ & Black oxide coating & PEO S1 \\
\hline $\mathrm{dry} / 2 \mathrm{~N}$ & $\times$ & $40 \mathrm{~m}$ (failed) & $1000 \mathrm{~m}$ \\
\hline lubricated $/ 5 \mathrm{~N} / \mathrm{v}=0.08 \mathrm{~m} / \mathrm{s}$ & $50 \mathrm{~m}$ & $75 \mathrm{~m}$ (failed) & $1000 \mathrm{~m}$ \\
\hline
\end{tabular}

(a)

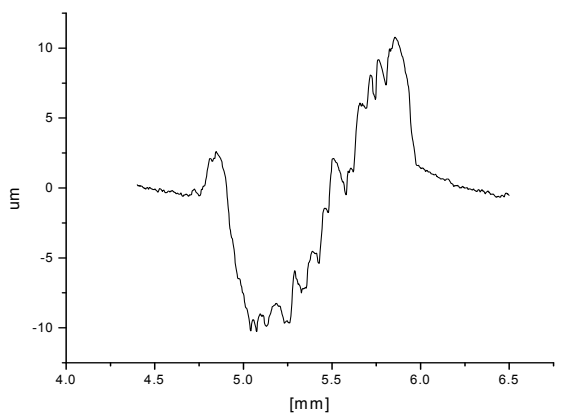

(b)

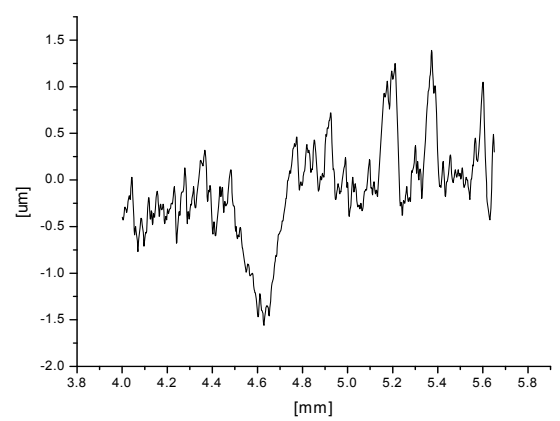

Figure 7: Transverse roughness on the wear trace of (a) $\mathrm{Zr}-2.5 \mathrm{Nb}$ substrate and (b) PEO coated sample S4 under $2 \mathrm{~N}$ load, dry air, rotating mode with $50 \mathrm{~m}$ and $1000 \mathrm{~m}$ sliding distances respectively.

Fig 8 shows the wear traces for selected samples tested in the dry and rotating mode. $1000 \mathrm{~m}$ wear distance was used on sample S1 after PEO process and after 5 and 10 days in autoclave (fig 8 (a)-(d)). Grinding polish was observed inside the wear trace of S1 (fig 8(b)) due to the high hardness of the PEO coating. The coating material had been compacted by the normal load. This behaviour was because the PEO layer had been hardened due to autoclaving for 5 days. However, after 10 days in the autoclave, the outer layer of PEO coating on sample S1 was softened (both by autoclave treatment and heat produced during wear tests) and was pushed away from the wear trace and became wear debris. However, the dense oxide underlayer was still intact. Fig 8 (c), (d) are the wear trace on sample S4 after 10-day autoclave treatment. The $1000 \mathrm{~m}$ wear test caused the penetration of the PEO coating and the wear loss from the substrate. Inside the wear trace, deep scratches (grooves), caused by "three body" debris 
wear, were observed on the soft substrate material. The uncoated sample with 5day autoclave treatment showed evidence of plastic deformations in its wear trace (fig $8(\mathrm{~g}),(\mathrm{h}))$. Scaly debris was observed after $50 \mathrm{~m}$ wear test which means the oxide formed in the autoclave was relatively soft.

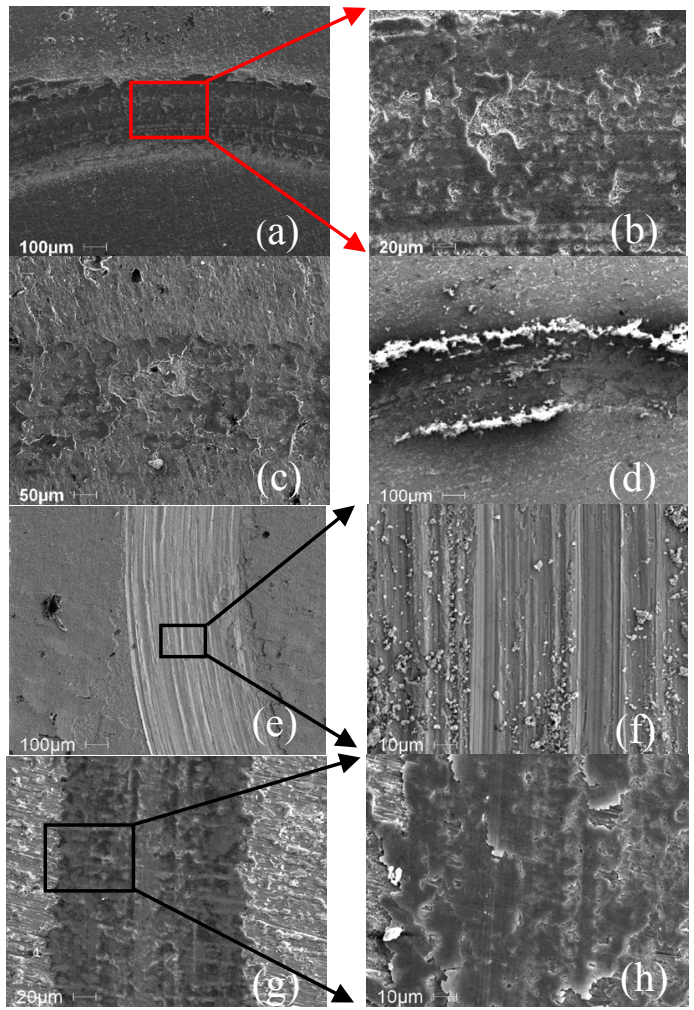

Figure 8: $\quad$ Rotating wear trace on different PEO coatings and substrate: $(\mathrm{a}, \mathrm{b})$ $\mathrm{S} 1,1000 \mathrm{~m}$, before autoclaved; (c), (d) S1 1000m, 5 and 10 days in autoclave; S4, 1000m, (e), (f)10 days in autoclave; (g), (h) $\mathrm{Zr}$ $2.5 \mathrm{Nb}$ substrate $50 \mathrm{~m}, 5$ days in autoclave.
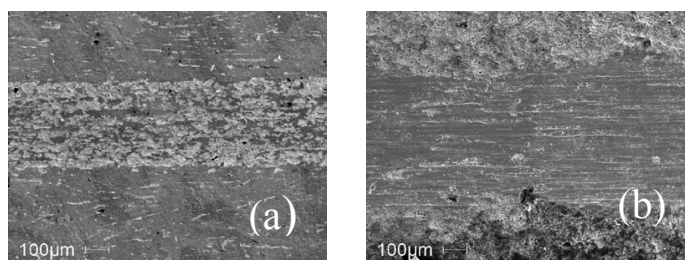

Figure 9: $\quad$ SEM showing wear trace of (a) sample S1, (b) black oxide coating.

After the rotating mode wear tests, sample S1 was chosen for comparison with the black oxide coating because of its excellent wear resistance. Because of the curved surface of black oxide coating sample, a reciprocating mode was 
used. The wear traces are shown in fig 9. 1000m and $75 \mathrm{~m}$ wear distances were used on S1 and black oxide coating (failure distance), respectively, under the same $5 \mathrm{~N}$ load and lubricated condition. The wear trace on black oxide coating was much wider and deeper than that on sample S1 and it is clearly seen that all coating material was removed from the substrate. Thus the PEO coating had much better wear resistance than the black oxide coating.

\section{Conclusions}

Investigations into the effects of process (electrolytic and electrical) parameters on PEO coating formation on $\mathrm{Zr}-2.5 \mathrm{Nb}$ alloy and the corrosion and wear properties of the coatings showed that:

1. For the limited PEO process parameters examined, the best coatings in terms of its integrity (dense, continuous) were produced at higher $\mathrm{Na}_{2} \mathrm{SiO}_{3}: \mathrm{KOH}$ ratios (10:1 cf 1:1), i.e. lower $\mathrm{PH}$ values, and lower current densities, i.e. longer processing times.

2. The commercial, thin, black oxide coating showed the best corrosion resistance in the potentiodynamic polarization tests. PEO coatings also improved the corrosion resistance of the $\mathrm{Zr}-2.5 \mathrm{Nb}$ substrate (the polarization resistance $\left(R_{p}\right)$ was one to two orders of magnitude higher than the substrate).

3. $5 \mu \mathrm{m}$ thick PEO coatings have a much higher wear resistance than the commercial autoclaved black oxide coating under both dry and water lubricated conditions. Grinding polish was observed on the PEO coatings which enhanced the hardness of the coating surface. The commerciallyproduced black oxide coating had a wear resistance that was just slightly better than the substrate.

4. PEO coatings made from $10: 1$ of $\mathrm{Na}_{2} \mathrm{SiO}_{3}$ : $\mathrm{KOH}$ proved to have much better corrosion resistance and lower weight gains than the $\mathrm{Zr}-2.5 \mathrm{Nb}$ substrate after 30 days in autoclave. The black oxide coating had a very low weight gain value in the first 10 days but at 30 days, the final weight gain was very close to the PEO samples made at 10: 1 electrolyte ratio. A white, soft oxide formed beneath the PEO coating, replacing it slowly, especially on PEO samples made at a 1:1 electrolyte ratio. The original thin black oxide coating turned to a thick, flocculent structure which had inferior in corrosion resistance as measured in potentiodynamic polarization tests after autoclave testing.

\section{References}

[1] Holt, R. A., In-reactor deformation of cold-worked $\mathrm{Zr}-2.5 \mathrm{Nb}$ pressure tubes. Journal of Nuclear Materials. 372 pp. 182-214, 2008.

[2] Warr, B. D., Elmoselhi, M. B., Newcomb, S. B., McIntyre, N. S., Brennenstuhl, A. M., \& Lichtenberger, P. C., Oxide characteristics and their relationship to hydrogen uptake in Zirconim alloys, Zirconium in the Nuclear Industry. ASTM STP 1132, American Society for Testing and Materials, Philadelphia. pp. 740-757, 1991.

[3] Northwood, D., Meng-Burany, X. \& Warr, B: Microstructure of Zr-2.5Nb alloy pressure tubing. Zirconium in the Nuclear Industry. ASTM STP 1132, 
American Society for Testing and Materials, Philadelphia, American Society for Testing and Materials, Philadelphia, pp. 156-172, 1991.

[4] B. Cox; Some thoughts on the mechanisms of in-reactor corrosion of Zirconium alloys. Journal of Nuclear Materials. 171 pp. 331-368, 2005.

[5] Snizhko, L. O. \& Yerokhin, A. L; Anodic processes in plasma electrolytic oxidation of aluminum in alkaline solutions. Electrochimica Acta. 49 pp. 2085-2095, 2004.

[6] Yerokhin A. L., Nie X., Leyland, A., Matthews A., Dowey S. J. Plasma electrolysis for surface engineering Surface and Coating Technology. 122 pp. 73-93, 1999.

[7] Barik, R. C., Wharton, J. A., Wood R. J. K., Stokes K. R. \& Jones R. L. Corrosion, erosion and erosion-corrosion performance of PEO deposited $\mathrm{Al}_{2} \mathrm{O}_{3}$ coatings. Surface \& Coating Technology. 199 pp. 158-167, 2005.

[8] Guang, Y. J., Xia, Y., \& Li, G.; Growth mechanism and corrosion behaviour of ceramic coatings on $\mathrm{Al}$ produced by autocontrol AC pulse PEO. Surface \& Coatings Technology. 202 pp. 4602-4612, 2008.

[9] Yerokhin A. L., Shatrov, A. Samsonov V., Shashkov P., Pikington A., Leyland A. \& Matthew A. Oxide ceramic coatings on aluminium alloys produced by a pulsed bipolar plasma electrolytic oxidation process Surface \& Coatings Technology. 199 pp. 150-157, 2005.

[10] Ghasemi, A., Raja V. S., Blawert C., Dietzel W. \& Kainer K. U. Study of the structure and corrosion behaviour of PEO coatings on AM50 magnesium alloy by EIS Surface \& Coatings Technology. 202 pp. 35133518, 2008.

[11] Yerokhin A. L, Nie, X., Leyland, A. \&Matthews, A. Characterisation of oxide films produced by PEO of a Ti-6Al-4V alloy. Surface and Coating Technology. 130 pp. 195-206, 2000.

[12] Klapkiv, M. D. Povstyana N. Yu. \& Nykyforchyn H. M. Production of Conversion Oxide-Ceramic Coatings on Zirconium and Titanium Alloys Material Science, 42(2), pp. 277-2862006.

[13] Pauporte T., Finne J., Kahn-Harari A., Lincot. D. Growth by plasma electrolysis of zirconium oxide films in the micrometer range. Surface \& Coating Technology. 199, pp:313-219, 2005.

[14] Bojinov, M., Karastoyanov, V., Kinnunen P. \& Saario T. Influence of water chemistry on the corrosion mechanism of a zirconium-niobium alloy in simulated light water reactor coolant conditions. Corrosion Science. 52 pp. 54-67, 2010.

[15] Yilmazbayhan A., Breval E., Motta A. T. \& Comstock R. J. Transmission electron microscopy examination of oxide layers formed on $\mathrm{Zr}$ alloys. Journal of Nuclear Materials. 349 pp. 265-281, 2006.

[16] Northwood D. O., \& Kosasih U. Corrosion and Hydriding Behavior of Zr$2.5 \mathrm{Nb} \mathrm{Wt}$. Pct $\mathrm{Nb}$ Alloy Nuclear Reactor Pressure Tubing. Journal Materials for Energy System. 4(1), pp.3-15, 1982.

[17] Parfeno B. G., Gerasimov V. V. \& Venediktova G. I., Corrosion of Zirconium and Zirconium alloys IPST Press, Wiener Bindery Ltd., Jerusalem. 1969. 